\title{
From Play to Political Action: Prosumerism on Fanvideo Meme Production
}

\author{
André Luiz Maranhão de Souza-Leão ${ }^{1}$ \\ Bruno Melo Moura ${ }^{1}$ \\ Vitor de Moura Rosa Henrique ${ }^{1}$ \\ Walber Kaíc da Silva Nunes ${ }^{1}$ \\ Italo Rogerio Correia de Santana ${ }^{1}$
}

${ }^{1}$ Universidade Federal de Pernambuco, Recife, PE, Brazil

Received 23 October 2019. This paper was with the authors for two revisions. Accepted 07 October 2020.

First published online 27 October 2020.

Editor-in-chief: Carlo Gabriel Porto Bellini(D) (Universidade Federal da Paraíba, João Pessoa, PB, Brazil)

Associate editors: Maribel Suarez (ID) (Universidade Federal do Rio de Janeiro, Rio de Janeiro, RJ, Brazil)

Reviewers: Maria Carolina Zanette (DE) (NEMA Business School, Brazil) and an anonymous reviewer

Editorial assistants: Kler Godoy and Simone Rafael (ANPAD, Maringá, PR, Brazil) 


\section{ABSTRACT}

Fans are singular productive consumers. One of their typical practices is the production of fanvideos. An increasingly common trend in fanvideos is the creation of memes, a phenomenon of the modern internet related to ironic humor. This study aimed to analyze how fans, based on media texts, related to successful popular culture franchises. For this purpose, we performed an interpretive content analysis of fanvideos based on popular culture franchises posted on YouTube. Results demonstrate that meme fanvideos are made for play with and through the franchises, play dirty tricks, and criticize the politics. It happens by a variety of types of performances and techniques that dialogue both with the fictional universes and with different spheres of social life, often revealing an attitude of social criticism. Nevertheless, this interface makes room for a reproduction of prejudiced practices that target stigmatized identities. This process illustrates the intensive use of information and communication technologies and the ubiquity of the media, as well as the political tensions increasingly present in ordinary social life. These outcomes show how productive consumer behavior collapses with other social spheres when the meaning of products and brands is appropriated and re-signified through skilled creative consumer practices.

Keywords: meme; fanvideo; fan culture; prosumer; interpretive content analysis.

JEL code: M310.

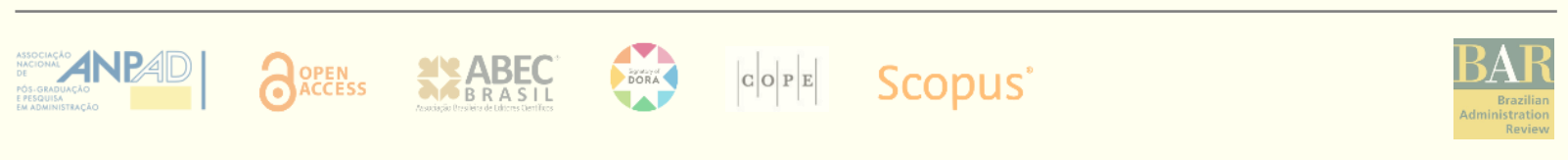




\section{INTRODUCTION}

The impact of technological transformations strongly permeates the contemporary cultures (Lévy, 2007). This can be verified in popular culture, which industry (i.e., entertainment) is increasingly attempting to get closer to its consumers (Kizgin, Jamal, \& Richard, 2018; Peñaloza, 1994). In a singular way, part of these industries' consumers are fans that commonly engage with the consumed products (Hills, 2013). This practice was enhanced by technological advancement and by the media convergence, which provided the foundation for a participatory culture, whose members, based on common interests, produce collectively (Guschwan, 2012; Jenkins, 2006). Thus, fans are characterized by active consumption, which encompasses sharing of impressions and ideas, in a network of connected individuals who share common interests, marked by affection and involvement with the products they consume (Jenkins, 2006; Kozinets, 2001). Since fans collaboratively participate in the production of their own consumer experiences, Souza-Leão and Costa (2018) characterize them as prosumers. The notion of prosumption comes from the conception that consumption is inseparable from production (Ritzer, 2014), which has gained new relevance in a context of technological development and the emergence of Web 2.0 (Ritzer \& Jurgenson, 2010). From the new technological possibilities of virtual interaction, mainly through social networks, consumers begin to engage more intensively with the products they consume and start to produce content related to them (Boulaire, Hervet, \& Graf, 2010; Ritzer, Dean, \& Jurgenson, 2012).

One of the most productive acts from fans, which contributes to the consolidation of fan culture, is the creation of fanvideos (Jenkins, 1992). In the 1970s, this practice of content production has become possible due to the development of video production, editing, and distribution techniques. Nowadays, it is becoming increasingly relevant, due to Web 2.0 and the digital technologies (Freund, 2016; Stein \& Busse, 2009), as well as the possibility of online sharing, with YouTube being the main disclosure vehicle used by fans (Hilderbrand, 2007).

A recurring practice in fanvideos is its use for meme production, a phenomenon of the modern internet based on the creation of materials whose purpose is the generation of humor. Despite a conceptual overlap between memes and fanvideos, both are autonomous categories (Guadagno, Rempala, Murphy, \& Okdie, 2013; Shifman, 2012, 2014). The first is a type of video making developed by fans, mostly for fans, who may or may not intend to spread it on the web (Freund, 2016). Memes, on the other hand, are materials based on irony, produced from several sources (i.e., images, videos, audios) in order to go viral (Mina, 2019; Phillips, 2019).

Inserted in the logic of participatory digital culture, memes became popular for their contagious, public, and continuous propagation aspect (Guadagno et al., 2013; Shifman, 2012, 2014). Memes exemplify a process of transformation and democratization of the relationship of fans with media texts, which are re-signified in an appropriate environment for a rapid spread of creative content (Wang \& Wang, 2015).

Shiffman (2012) argued that memes are one of the cultural manifestations that allow us to understand the relationship between society and contemporary digital culture. It is a genre that

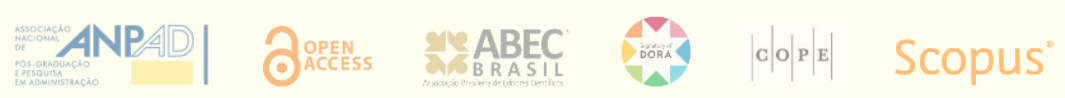


presents the social positioning of parodies and is aligned to participatory cultures' developments, since individuals naturalize their lives using technologies (Jenkins, 2009; Wiggins \& Bowers, 2014). In this sense, we agree with Morreale (2013) about the importance of the memetic production on fanvideos by fans of popular culture, posted online on YouTube. Fanvideos are one of several fannish practices that exemplify how they engage to demonstrate their relationship with the cultural objects (Jenkins, 1992).

According to Kozinets (2001), this relationship provides a range of fannish possibilities, such as positive role models, exploration of moral issues, knowledge and ideas, explorations of erotic desire, and feelings of communities, which works as utopias that unite impossibility and dream, representing a deep motivational power and desire. These desires are reflected in the expression of personal and political particularities that fans usually carry out in their creation and modification of franchise content (Neville, 2018).

Based on this, this research aims to analyze how fans express themselves through memes produced in fanvideos, based on media texts related to successful popular culture franchises. Thus, the investigation assesses how the production of memes by fans reveals their desire to participate in the meaning making of the media texts to which they link. In order to fulfill this purpose, our study has the following specific objectives: (a) describe the production process of the meme fanvideos; (b) identify the meanings presented in the meme fanvideos; and (c) interpret theoretically the meme fanvideos production. For this purpose, the work assumes a partially inductive character, insofar as we use theoretical foundation as a means of providing the study with a lens to both ground and interpret the phenomenon (Leão, Mello, \& Vieira, 2009; Timmermans \& Tavory, 2012), without such theoretical conceptions having been previously established as constructs.

The growing relevance of popular culture, associated with engaged fan practices, indicates the pertinence of investigation of this phenomenon by consumer culture theory (CCT), a consumer research field circumscribed in marketing discipline. Specifically, the creation of memes by productive consumers has gained prominence in researches of fan culture (e.g., Papailias, 2018; Shifman, 2012; Wu \& Ardley, 2007). In addition, understanding fan action as prosumption (Souza-Leão \& Costa, 2018) results in a comprehension of their role under a market productivity logic (Chen, 2011; Collins, 2010). This set of possibilities indicates a potential for interdisciplinary theoretical contribution to the research field, as well as practical implications, based on the singular phenomenon investigated.

\section{THEORETICAL BASIS FOR THE STUDY}

As developed in the elaboration of the research problem, the present study focuses on the production of meme fanvideos. To this end, the research assumes the fan as a prosumer who produces fanvideos as user-generated content in a context of participatory culture, as shown in Figure 1. The sections below articulate these connections.

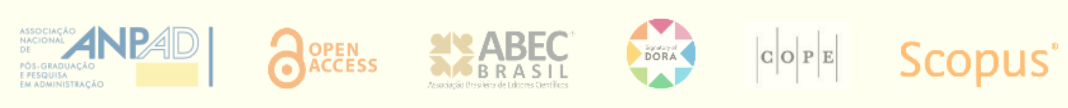




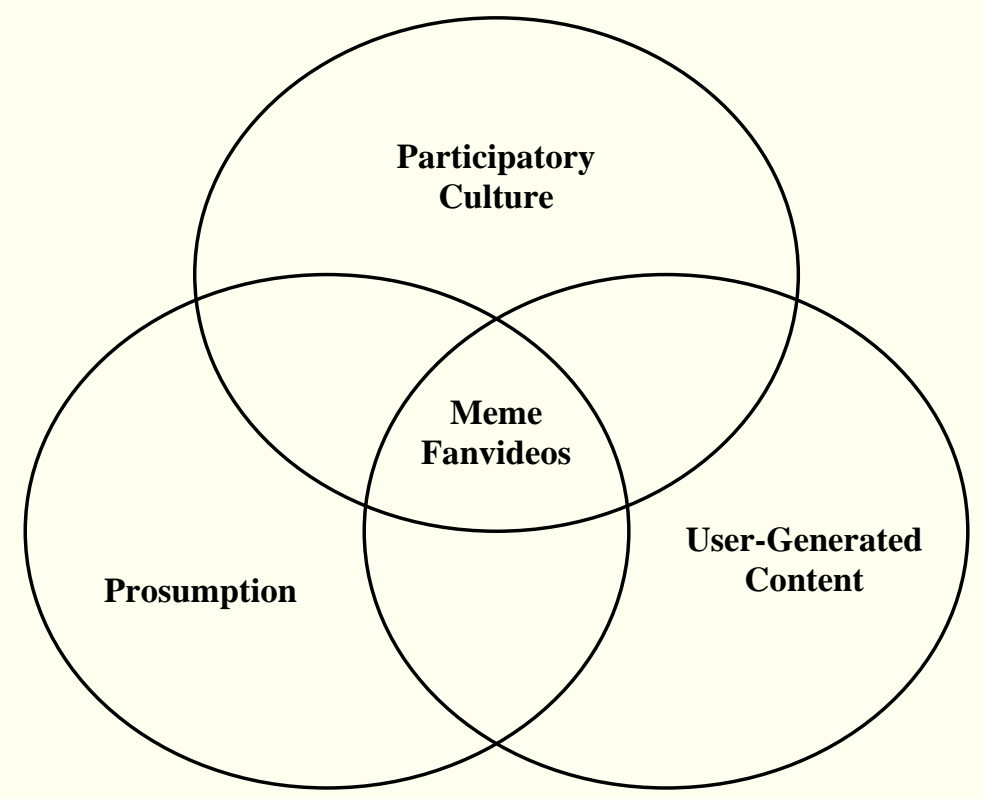

Figure 1. Conceptual framework

\section{The prosumerist face of the fans}

Due to the level of engagement with the products they consume, fans distinguish themselves from ordinary consumers by seeking to consolidate and validate the values that make them stand together. Besides, they contribute to the enthusiasm in the consumption (Hills, 2013), and assign unique meanings to media texts (Busse \& Gray, 2011; Hackley \& Hackley, 2018). Thanks to the social interactions they form among themselves, they have established an effective exchange with the media products (Guschwan, 2012; Jenkins, 2006). On the other hand, they usually reverberate the media products through reinterpretations, new meanings, and even new materials, becoming natural content producers (Hills, 2002). Since fans are productive consumers, we follow Souza-Leão and Costa (2018) in the understanding that they can be considered prosumers.

The sense of prosumer was originally presented by Toffler (1980), based on the assumption that the consumers, by becoming part of the production process, are no longer only consumers. This sense had a fast entrance on marketing literature promoted by Kotler (1986), but it was not widely used until Ritzer (2014) reconceptualized it, arguing that the division between production and consumption never really existed; it was the industrialization process that shaped this split. From this argument, he proposes the understanding of the relationship between production and consumption as a continuum, at whose extremes are the positions of prosumer-as-producer and prosumer-as-consumer.

Thus, what was once called simply consumer could now be understood as a prosumer (i.e., prosumer-as-consumer) since, in addition to consuming, s/he performs functions that previously belonged exclusively to the production system (Cova, Dalli, \& Zwick, 2011; Ritzer, 2014). Such attributions can be associated by producers to consumers as compulsory and objective, as

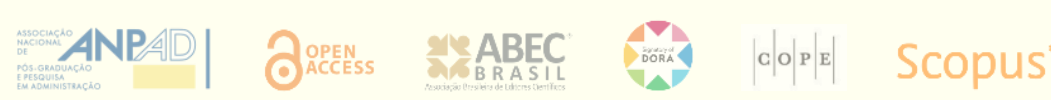


conceptualized by Toffler (1980) and alluded by Ritzer (2014); however, they can also be performed spontaneously and subjectively (Cova \& Cova, 2012; Ritzer \& Jurgenson, 2010), aligned to what we introduced as productive consumption of fans.

Consumer productivity has been stimulated through new information and communication technologies, mainly through the interactions on the internet (Chen, 2018; Sugihartati, 2020), boosted by the Web 2.0 (Collins, 2010; Laughey, 2010). Due to this scenario, Ritzer and Jurgenson (2010) name contemporary productive consumers as Web 2.0 prosumers - people who demonstrate a unique productive competence, being able to modify the productive process of what they consume, as well as influence it by elevating the degree of awareness of products and services. This process is elaborated in the context of virtual environments, especially through the intense access to social media (Ritzer, et al., 2012; Zajc, 2015).

More than performing an operational productive role in consumption, Web 2.0 prosumers become specialized consumers and act as co-producers of their own consumer experiences (Ritzer, 2014; Stuart-Menteth, Wilson, \& Baker, 2006). This usually occurs jointly and engaged (Morreale, 2013; Sugihartati, 2020), through dialogic relations (Hartmann, 2015; Ritzer, 2014), when they are responsible for sharing content and materials related do the consumer products (Collins, 2010; Ritzer et al., 2012).

This process takes place through a participatory culture (Souza-Leão \& Costa, 2018), which refers to the collective production and sharing of knowledge, opinions, feelings, and experiences that can result in interactivity and sociability practices (Guschwan, 2012; Jenkins, 2006). According to Jenkins (2006), it was the convergence of media and the appropriation of technologies that originated the participatory culture. It happens when individuals traffic through different media, building new meaning to the content they consume, transiting from a sociocultural isolation to active participation in groups that are open to their productions.

Fan culture is complex and multidimensional and became one of the most relevant contemporary participatory cultures, generating economic and cultural repercussion (Hills, 2013; Sandvoss, 2005). It has been consolidated since the 1970 s and is gaining larger figure with the advent of the Web 2.0 technologies (Freund, 2016), making it easier for individuals to come together and cooperate in producing and sharing popular culture (Guschwan, 2012; Jenkins, 2006).

\section{Fanvideos generated content}

Content production is one of the typical practices of Web 2.0 prosumers (Daugherty, Eastin, \& Bright, 2008; Ritzer, 2014). Among them, user-generated content (UGC) has grown as shared online productions increase their views. People producing UGC look for expressing their identity, develop social interactions with other consumers, get or propagate information, or simply entertain (Daugherty et al., 2008; Muntinga, Moorman, \& Smit, 2011).

Many UGCs are related to brands and products and are usually produced both to influence others and for hobby and fun (McKenzie, Burkell, Wong, \& Whippey et al., 2012; Tapscott \&

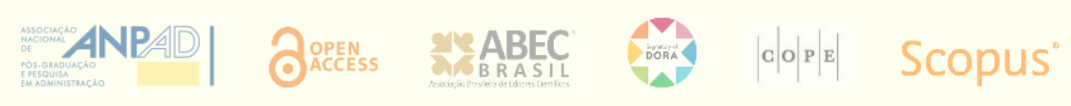


Williams, 2006). It can change the perceptions about brands, whether favorably or unfavorably (Christodoulides, Jevons, \& Bonhomme, 2012; McKenzie et al., 2012). This type of material is making large media and entertainment industry groups better understand their consumers and get closer to them (Van Dijck, 2009), since it is a means to create social connection (Delwiche \& Henderson, 2012).

Social networks have gained prominence for the propagation of UGC, by granting the possibility of democratizing and popularizing this type of content. YouTube became the main platform for publishing UGC, making the videos produced by the audience one of the most emblematic types of UGC (Jung \& Shim, 2014). It happened both because of its Web 2.0 operative technology and its growing cultural and economic relevance (Van Dijck, 2013). The platform started as a site aimed at individuals able to produce, share, and watch videos. Over time, YouTube turned into a social network and search engine hybrid. This made it popular, not exactly for its innovative technological competence, but for the sense of community defined between its users (Van Dijck, 2009, 2013). According to Burgess and Green (2009), by offering its users the possibility to post their self-made videos, YouTube has become influential in stimulating collective creativity.

Among the videos produced as UGC, a specific type concerns those made by fans of media products (Jung \& Shim, 2014). Fanvideos production originated in the 1970s, and the popularization of VCRs and handycams enhanced them over the next two decades (Stein \& Busse, 2009). Continuing to be supported by technological development, they became a popular practice in this century, especially amidst fan communities, due to the ease of access to digital technologies for recording, editing, and sharing videos (Freund, 2016).

Jenkins (1992) argues that fanvideos are one of the most relevant fan practices, due to the resignification of the media texts. It has implications for media culture consumption, by establishing an attachment between media products and their consumers. It is one of the ways in which they perform their skills as 'poachers,' when they manifest their continuous desire to discover and spread new contents about what is consumed. Due to the exchange of consumption experiences and the interaction with other fans, especially in fandoms (Duffett, 2013; Hills, 2013), fans are able to discuss political transformations (Booth, 2013) in which they use and reframe the fictional universe of the franchises to explain local and personal phenomena (Hills, 2010). The establishment of the virtual era generated bonds between fans, which enables them to be a source of observation for understanding current social practices, including the sense of belonging in a given culture that unites individuals with similar tastes (Kozinets, 2001).

In consequence, the main reason for fans to produce fanvideos is the wish to rewrite the media texts. It happens in order to fit original content to their preferences, to fix what they consider to be flaws in the narratives, or to highlight contents considered to have been superficially approached on the original works (Freund, 2016; Stein \& Busse, 2009). By producing and sharing videos that have media products as the central focus of their narratives, fans interact with each other, creating a sense of community (Stein \& Busse, 2009). 
One way to reformulate and give new meaning to media texts is by using humor. Much of the fanvideos production occurs through the elaboration of parodies (Morreale, 2013), especially those that are produced to be massively shared on social networks. Also called memes, it is one of the most recent and relevant ways to generate irony - a peculiar kind of humor - through online platforms (Mina, 2019; Phillips, 2019).

\section{Memes representation to participatory culture}

Because it is a type of parody, the culture of producing and reproducing memes cannot be limited to a humorous concept. Memes are commonly used as tools to express political positions (Ross \& Rivers, 2017), social and cultural manifestations (Kligler-Vilenchik \& Thorson, 2016; Nissembaum \& Shifman, 2015), and, mainly, content that unites individuals by their spontaneous participate activity (Jenkins, 2009; Shiffman, 2014). For Wiggins and Bowers (2014), memes function as artifacts that emphasize intentional production and consumption among different members of participatory cultures.

The meme genre is established when members of the participatory culture consider ironic humor as a source of iteration with other individuals (Phillips, 2019), allowing the union of different people as long as there is engagement on that produced and reproduced content (Shiffman, 2012; Wiggins \& Bowers, 2014). For consequence, this genre can indicate how the virtual physicality present in the participatory culture became increasingly inseparable from Web 2.0 context. It works as artifacts that reiterate the social and cultural role of the intimate relationship between the new media landscape and the growing participation of individuals (Jenkins, 2009; Wiggins \& Bowers, 2014).

Meme contents can be understood as a varied form of puns and jokes use in order to get popularized (Zanette, Blikstein, \& Visconti, 2019), and refers to cultural productions made through imitations developed using images, texts, music, and videos (Ross \& Rivers, 2017). As a reflection of the environment in which it was established, the meme genre is rooted in complex social dynamics, where the intense work of coordination and generalized imitation is established in a decentralized and apparently chaotic public sphere (Knobel \& Lankshear, 2007; Nissembaum \& Shifman, 2015). Shiffman (2012; 2014) considers that YouTube was fundamental to popularize the meme genre. Like other sites that adhere to the logic of Web 2.0, the platform facilitated the production and sharing of memes in videos. The platform's contribution is not limited to videos: the possibility of seeing the visibility achieved by the meme, by providing the number of views of the videos, boosted the interest of users to become content producers.

Despite the share and modified interest, memes should not be confused with 'viral' content. This type of content works like an epidemic: it spreads quickly from person to person, reflecting marketing strategies that focus on the delivery mechanism and audience reach, which in turn ignores cultural and social aspects (Knobel \& Lankshear, 2007; Shifman, 2012). The content of meme videos is based on user participation. It expresses the involvement of those who produced it, reflecting and attracting the creative engagement of other users present in a range of actions

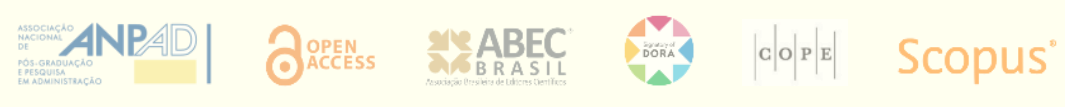


and communicational interactions from naive humor to political criticism (Nissembaum \& Shifman, 2015; Shifman, 2012).

The content of memes is not only forwarded but also shared (Shifman, 2014). While the former is just an attempt to hand on some content, the later reflects the spreadability present in the participatory culture (Jenkins, Ford, \& Green, 2013). Thus, memes summarize the era of the convergence culture, when individuals move from socio-cultural isolation to a convergence that unites them with similar ones; they both appropriate the available technologies, as they converge between different types of media (Guschwan, 2012; Jenkins, 2006). The meme genre presents an overlap, via active participation, of the practices of fans who wish to reframe the media texts they consume (Shifman, 2012).

\section{METHODOLOGICAL PROCEDURES}

We conducted the research through the analysis of Brazilian fanvideos representative of fanmade productions, placed accessible on YouTube, based on major popular culture franchises. They can be characterized as multifocal secondary data (e.g., films, videos, audios, photos), featured by the combined use of elements involving more than one human sense. Specifically, it is about a social practice analysis through visual documents (Flick, 2006).

We adopted the interpretive content analysis (ICA) as analytical method, since it can provide an adequate understanding of the plural meanings that signs of language may have (Baxter, 1991). As its name indicates, epistemologically, it is an interpretive research variety of content analysis. Hence, unlike its more established version, ICA propitiates a holistic access to the context of signification of a given text (Ahuvia, 2001; Drisko \& Maschi, 2015).

As recommended, ICA should not be executed by only one researcher (Ahuvia, 2001). Even though it requires a more complex analytical operation and imposes the necessity for a constant exercise of reflexivity, this can prevent idiosyncrasies on the data interpretation. Besides, it becomes a more reliable process, as it averts inconsistencies in the analysis (Drisko \& Maschi, 2015).

The application of ICA begins with the data collection procedure, since its foundations must be considered in the data source definition and in the criteria to be used to qualify them as phenomenon of relevance for the investigation. The analysis, then, is oriented by a coding process based on schemes of hierarchy and interrelationship of the data, culminating in the generation of code definitions and relations that represent the phenomenon under investigation (Drisko \& Maschi, 2015).

For the research corpus construction, a preliminary evaluation of fanvideos on YouTube was undertaken, leading to the identification of material produced based on three exemplary popular culture franchises: Game of Thrones, Harry Potter, and Star Wars. The former achieved the status of the most emblematic television program in popular culture in the 2010s by adapting a literary saga (i.e., A Song of Fire and Ice) with a great resonance on the web (Milkoreit, 2019; Sarikakis, 
Krug, \& Rodriguez-Amat, 2015). Also known as Wizarding World, the fictional universe originated in the Harry Potter book series has great prestige among fans around the world, not only for its literary content, but also for the films that adapt and expand its content (Martens, 2019; Souza-Leão \& Costa, 2018). Finally, Star Wars is considered one of the most notorious cinematic phenomena in history, booth by its notoriety in the entertainment industry and the impact it has among fans of all ages (Jenkins, 2003; Taylor, 2014).

For the selection of the videos, three criteria were adopted: (a) correspondence to some type of fanmade production, following the research problem; (b) creation by Brazilians, considering the empirical scope of the research; and (c) access to only non-professional or non-commercial channels, revealing the amateur work of the fans. Thus, videos whose memes escape the popular culture context, that were produced in languages other than Brazilian Portuguese, or that were produced and broadcast by professional channels, were disregarded.

First, we collected videos based on a search for keywords, having their content verified in order to represent a fanmade production. Following this procedure, since the platform makes suggestions of other videos associated with the one running, these were verified based on the same principle. We repeated this action until the search tool returned only videos already collected. From this, the platform database was saturated and was possible to guarantee the representativeness of the research corpus (Bauer \& Aarts, 2002). In all, we collected 907 videos posted from March 2006 to July 2019. Table 1 presents the distribution by franchise.

Table 1

Research corpus

\begin{tabular}{lcc}
\hline & Franchise & Quantity of videos \\
\hline Game of Thrones & & 124 \\
Harry Potter & & 343 \\
Star Wars & 440 \\
\hline
\end{tabular}

Such videos can be understood as productions resulting from interactions between consumers of a public brand (i.e., franchises) (Arvidsson \& Caliandro, 2015). Because they are part of popular culture, we assume these active consumers as fans (Jenkins, 1992). Consequently, we adopted Shifman's (2012) conception that memes production is a typical fan activity.

The data analysis was undergone in four stages, according to Figure 2: classification of the videos in categories created to represent the aspects of their narrative and technical characteristics, as well as how the franchises were approached; codification of the categories considering the empirical context of the video productions; definition of fanmade videos patterns, through the code relations, syntactically related to the categories; definition of themes conducting the memetic production. 


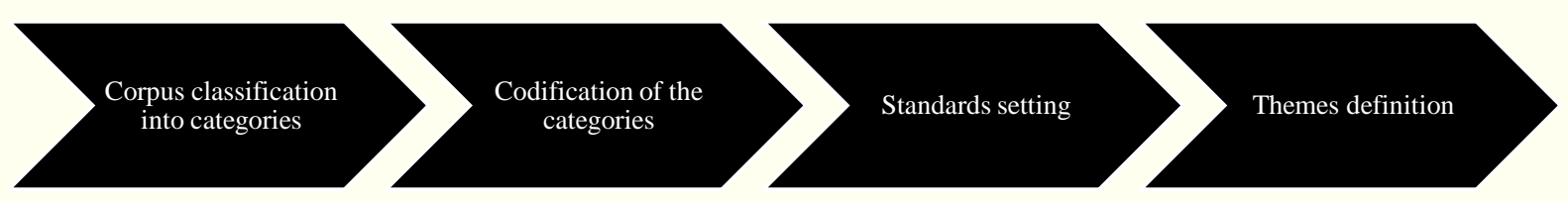

Figure 2. Analysis process

The research was conducted through a collaboration of five researchers. Three of them collected the data and the other two determined the videos that would come to compose the research corpus. One of these two defined the analytical categories, corresponding to the first stage of data analysis. As a first step to the second stage of data analysis, the researchers responsible for data collection performed the coding of the research corpus, by means of inter-coding reliability (Miles, Huberman, \& Saldana, 2014). The pair responsible for validating the research corpus accompanied and reviewed this process, culminating in the final validation of the second stage of analysis. The same pair performed the third stage of data analysis, scrutinizing the relationships of the codes and identifying the research corpus patterns. The fourth stage of data analysis happened in the same way as the second. The first three researchers identified the meme themes through an inter-coding reliability process, which was reviewed and validated by the last two.

This process reflects the adoption of quality criteria of qualitative research (Hayashi, Abib, \& Hoppen, 2019; Paiva, Leão, \& Mello, 2011): composition of the research corpus in view of the representativeness of the investigated phenomena; researchers' reflexivity on the data analysis process; and researcher triangulation procedure. In addition, the following sections present a rich and thick description of the results.

In order to meet the specific objectives of our study, we divided the result description in three subsections, as described as follows: (a) the production process of the meme fanvideos is described through paths regarding technical aspects and the way the franchises are handled. It was obtained through the relationships between categories and codes elicited in the analysis; (b) the meaning presented in the meme fanvideos is inferred through the patterns identified in the analysis; (c) finally, we theoretically interpret the results. According to the partial inductive approach adopted, this return to the literature both retrieves concepts previously presented and advances toward other theoretical insights.

\section{PRODUCTION PATHS AND FRANCHISE HANDLING IN THE PRODUCTION PROCESS OF MEME FANVIDEOS}

To describe the production process of meme fanvideos, we relied on the patterns established through the relationships (third stage of data analysis) between categories (first stage of data analysis) and codes (second stage of data analysis). We identified six categories: two related to the technical characteristics of the videos examined, one about the focus of their narratives, and three regarding how the franchises are approached. Each of them was empirically evidenced in a certain number of codes.

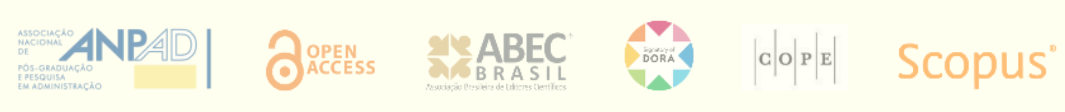


We classified technical categories in 'form' and 'format of production'. They concern, respectively, the way the production was developed, and the origin of the material used for it. The form of production is composed by four possibilities: 'composition', that are videos developed with fan-created material added to franchises' official material; 'editing', in productions that manipulate parts of the franchise's original content to develop narratives with other meaning; 'mixing', when fans mixture the franchise's official material with others, produced by third parties; and 'original' videos developed entirely from fan productions. There are three types of production format: 'animation', that are productions developed exclusively from animated elements (e.g., objects, images, scenarios); 'live action', that uses only real elements in the productions; and 'collage', combining various materials (e.g., images, animation, live action).

The narrative category, in turn, relates to the 'narrative technique' of the productions, which concern the form employed for the development of fanvideos. Those narrative techniques are eleven. 'Addition on scenes' are productions in which third party productions (e.g., songs, images) are added to franchises' official material. 'Compilation' uses clippings of franchises' official material gathered in a fan-defined sequence in which it assigns new meaning to them. 'Computer graphics' are franchise-related animation productions made through software. 'Dubbing' occurs in videos in which the franchise scenes are dubbed using original scripts, developing scripts completely different, or even using the franchise original scripts to narrate other materials. 'Subtitling', in turn, is used to maintain or alter the original scripts of the franchise productions. Videos in which elements (e.g., toys, animals, or objects) are used to stage the franchise were called 'puppetry'. Musical productions were called 'video clip'. 'Stop motion' are videos composed of photographs placed in sequenced movements. Finally, there are three types of franchise-related performances in which fans use costumes: cosplay features productions whose performances are made by fans who use trustworthy franchise costumes; in 'presentation with fantasy', fans use costumes similar to the ones in the franchises; and 'simple presentation' occurs when fans are characterized ordinarily to represent the franchise.

We designed Figure 3 to help understand how the categories and codes of this group combine, propitiating the identification of production paths. Two paths derive from original videos. Path 1 consists of live actions produced via puppetry, cosplay, presentation with fantasy, and video clip. Path 2, in turn, is composed of animations using stop motion or computer graphics. Other three paths are characterized using collage as the format of production. Path 3 is complementarily composed by composition with video clip and simple presentation. In Path 4, mixing is applied for dubbing, subtitling, addition on scenes, and video clip. Finally, editing is used on compilation and computer graphics (Path 5).

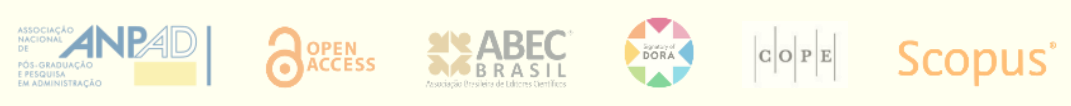




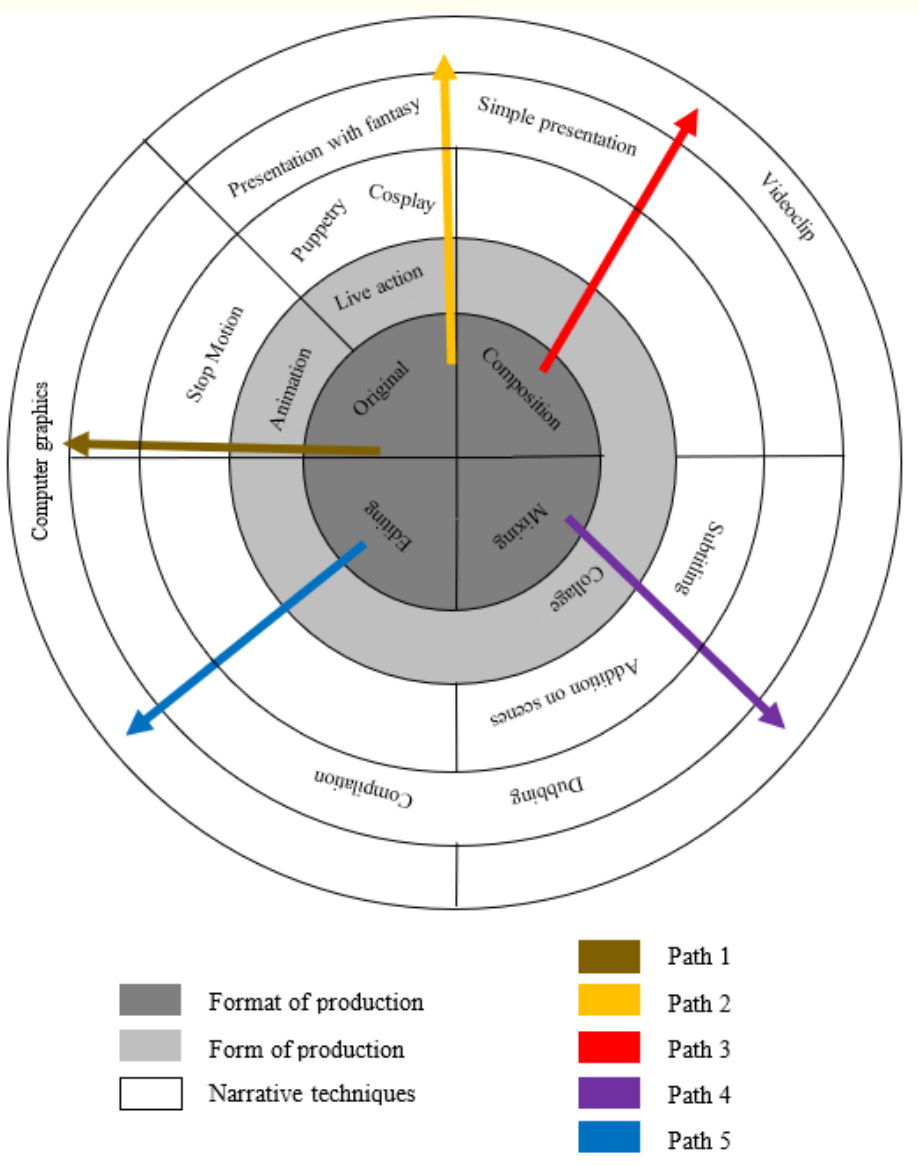

Figure 3. Technical-narrative paths

The three categories regarding the manners in which the franchises are handled and applied in the productions of the videos are as follows: 'references to the franchise', meaning the sphere in which the franchise is appropriated; 'presentation of the franchise', that is how the franchise is performed concerning the produced content; and 'approach of the franchise', which is the way fans make use of franchise content in their production. 


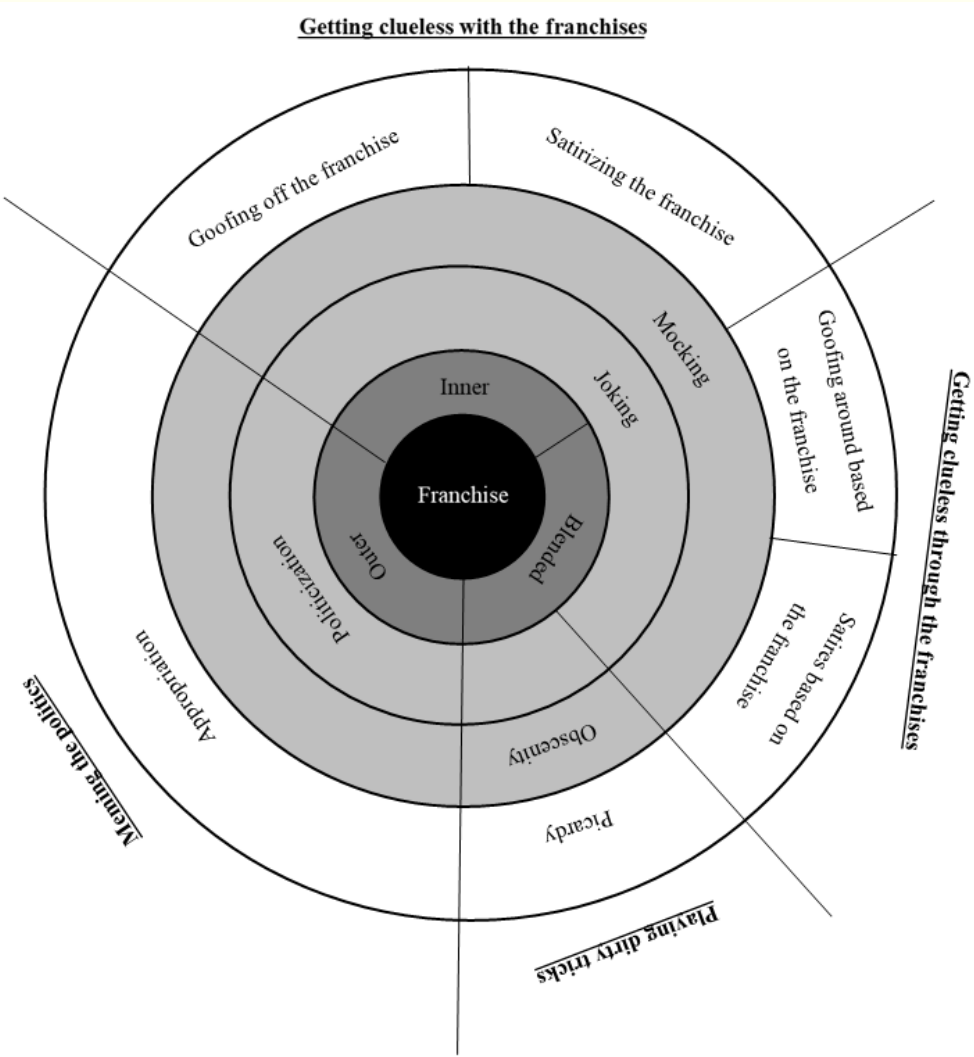

References to the franchises

Presentation of the franchises

Approaches of the franchises

Figure 4. Franchise handling patterns

References to the franchise occur in three ways: 'inner', concerning productions that cover themes exclusively about the franchise; 'outer', using the franchise to deal with subjects outside the franchise; and 'mixed', regarding productions that blend internal franchise themes with external affairs. Presentation of the franchise covers four possibilities: 'mocking', when the franchise is ridiculed or used to mock other subjects; 'joking', regarding kidding with franchise subjects or the use of it to treat other subjects humorously; 'obscenity', meaning the use of the franchise to vulgarly address other topics; and 'politicization', when the franchise is used to critique social issues.

Finally, there are six approaches of the franchise: 'goofing off the franchise' occurs when details of the franchises' fictional universe are presented in a humorous way; 'goofing around based on the franchise' is a means to treat other topics in a humorous way; 'satirizing the franchise' occurs when elements of the franchises' fictional universe are ridiculed; 'satires based on the franchise' are used as a means to ridicule other people's affairs; 'picardy' is used to approach other subjects in a vulgar way; and in 'appropriation' the franchises are taken as central point to address other topics. 
Figure 4 helps understand the patterns of franchise handling in the productions. Inner references can be made by joking or mocking, using the franchise for satirizing or goofing off, which represent a first pattern of our analysis. Outer references always have a politicization purpose, by means of appropriation, composing a second pattern. Blended references, in turn, drive the other two patterns: one based on obscenity and picardy, and other in which goofing around the franchises or satires based on the franchises are used either through joking or mocking.

\section{MEANINGS ON THE MEME FANVIDEOS}

Inference of the meanings presented in the meme fanvideos followed the thematic definition (fourth stage of data analysis), based on the patterns identified in the categories regarding how the franchises are handled (named in Figure 4) and in line with the production paths identified in the technical and narrative categories (see Figure 3). We discuss how each of these patterns is thematically illustrated on the fanvideos that, in turn, have their content and context explained and are exemplified through their respective thumbnails on YouTube.

We chose thumbnails as a resource to illustrate the data because they are synthetic of the content of the videos to which they refer. This is because they are used as a strategy to attract viewers (i.e., clickbait). It is, therefore, a public content, freely accessible on the platform (Bishop, 2018; Wood, 2020).

\section{Getting clueless with the franchises}

Fans use memes to have fun with the franchises, which can range from jokes to mockeries. In the first case, they goof off the franchises through three production paths, based on the following narrative techniques: cosplay, simple presentations, presentations with fantasy and puppetry (Path 1); computer graphics (Path 2); additions on scenes, compilation, dubbing, and subtitling (Path 4); and dubbing and compilation (Path 5). In relation to mockeries, they satirize the franchises through all production paths. The narrative techniques are used as follows: presentation with fantasy, puppetry, and video clip (Path 1); computer graphics and stop motion (Path 2); presentation with fantasy (Path 3); addition on scenes, compilation, dubbing, subtitling, and video clip (Path 4); and computer graphics (Path 5).

Regarding the jokes, fans make videos (Path 1) or work on mixing the franchise's scenes (Path 4) to 'create real-world-like situations'. In a video based on Game of Thrones, a typical dialogue of a mother preventing her child from going to a party is inserted in a scene between Daenerys and one of her dragons who, in the fictional universe, are called her sons. Based in 'Star Wars', a video - named 'Darth Vader no Trono' (i.e., Darth Vader on the Throne) - shows the Imperial fleet preparing for a battle as Darth Vader, featured by a cosplay fan, is pooping in the ship's bathroom while reading The Little Prince. Figure 5 shows the thumbnails of both videos. 


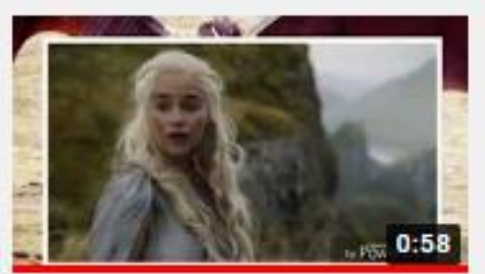

Game of Thrones especial (redublagem)

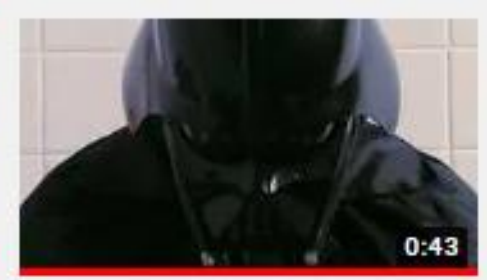

Darth Vader no Trono

Figure 5. Fanvideo thumbnails of memes about real-world-like situations.

Available on YouTube (accessed on August 13, 2020).

Fans also make videos that 'extol aspects of the franchises' fictional universes' in a funny way. In original (Path 1), mixed (Path 4), and edited (Path 5) videos, scenes, screenplays, and iconic soundtracks are combined with web-based memetic trends at the time of production to emphasize or give new meaning to unique moments in the franchises. For example, in a compilation of Game of Thrones scenes, various songs and memetic contents that are widely disseminated on the web are inserted to highlight situations when normally humiliated characters are exalted. Figure 6 was elaborated with the three examples of this group: the first video uses a viral music in Brazil in the year 2016 - Malandramente, meaning 'Rascally' - to characterize the change in posture of the character Sansa Stark in the season aired in the next year; the second video reproduces a national meme of a little girl running at the sound of Eurythmics' song Sweet Dreams, when a character tries to run for his life in the sixth season of the series; finally, a 1990's Brazilian hilarious song about a blonde guy - Lá vem o Alemão, meaning 'Here comes the German' - who falls in love easily was attached to represent a platonic love between the knight, Jorah Mormont, and his queen, Daenerys Targaryen.

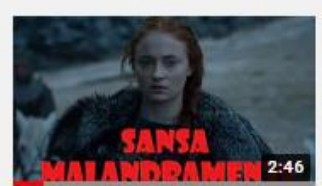

MALANDRAMENTE - Versão Sansa Stark (Game of..

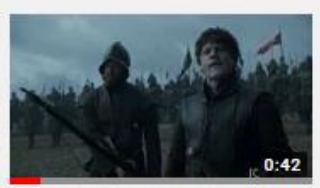

Game of Thrones: Correndo muito ao som de Sweet

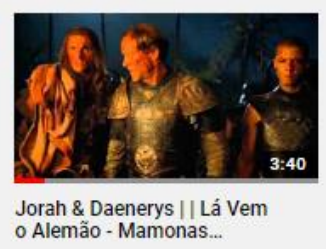

o Alemão - Mamonas...

Figure 6. Fanvideo thumbnails of memes that extol aspects of the franchises' fictional universes.

Available on YouTube (accessed on August 13, 2020).

Finally, videos from a variety of patterns (Paths 1, 2, 4, and 5) are produced to 'make fun of franchise characters'. The jokes are about situations they go through and the very role they play in the plots, going through some of their iconic speeches. It happens, for example, regarding sociability failures of key characters: Chewbacca's howling communication in Star Wars; Dumbledore's constant absence from the school in which he is principal in the Harry Potter films; and Sandor Clegane's - called on the video as Perdegueiro, o boca suja (i.e., the dirty mouth) recurring use of profanity in Game of Thrones. The three examples are shown by their respectively thumbnails in Figure 7. 


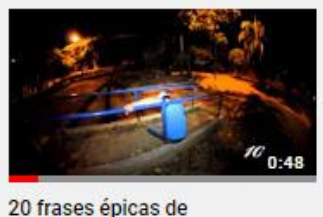
20 frases épicas de
Chewbacca

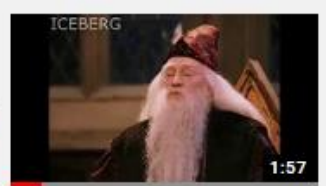
YTPBR - Harry Potter -
ESTUDANTES

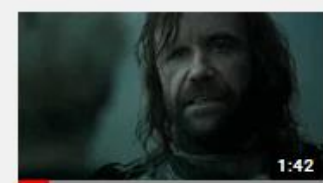

Perdigueiro, o boca suja

Figure 7. Fanvideo thumbnails of memes that make fun of franchise characters.

Available on YouTube (accessed on August 13, 2020).

Following the same logic, but in the opposite direction, fans of Harry Potter and Star Wars make mockeries to 'ridicule franchise characters'. It happens through original (Path 1) and mixing (Path 4) videos that follow this line based on the suggestion that the characters would be drugged. Scenes in which the mystical part of the Harry Potter and Star Wars universes are explained (i.e., Wizarding World and Jedi powers) are recreated with the characters being dubbed as if under the influence of some hallucinogen (both presented in Figure 8).

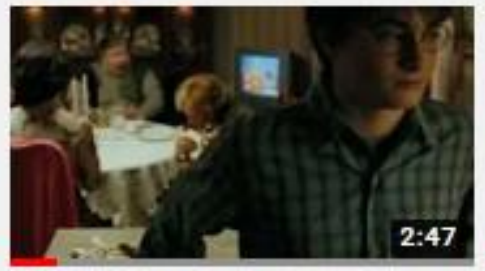

Harry Potter Maconheiro Dublagem

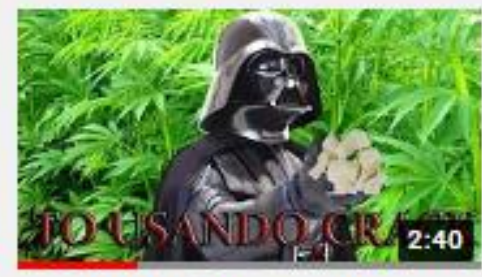

Drogas e Zueira \#2 - Star Wars O Despertar Da Zueira

Figure 8. Fanvideo thumbnails of memes elaborated to ridicule franchise characters.

Available on YouTube (accessed on August 13, 2020).

The same is done to 'ridicule aspects of the franchises' fictional universes'. In videos of all production paths, narrative construction, screenplays, storylines, trailers, and soundtracks are scrambled using web-based memetic content, both Brazilian (e.g., Afternoon Movie Season, Faustão voice, funks) and international (e.g., Google Robot Voice, Hitler images). In Figure 9, the first thumbnail (top line, left) is a remake of Fantastic Beasts and Where to Find Them - a prequel for the Harry Potter movies - trailer, which follows a unique - eccentric and silly - way to present movies to the Brazilian audience. In a similar sense, the second thumbnail (top line, middle) is related to a trailer of Episode VII from Star Wars narrated by Fausto Silva (i.e., Faustão), a very popular television host in Brazil. The next thumbnail (top line, right) presents the Darth Vader's theme song (i.e., 'The Imperial March') mixed as a funk song. The last two videos (bottom line thumbnails) are reactions to Game of Thrones plots: in the first (left), Google Robot narrates season five; the other (right) presents Hitler - from Der Untergang, a very famous German movie - furious with the death of a major character. 


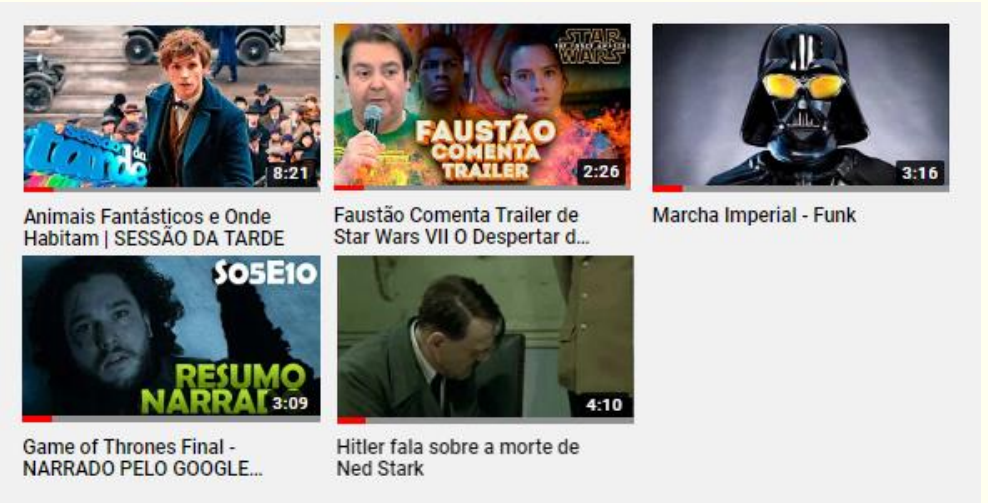

Figure 9. Fanvideo thumbnails of memes elaborated to ridicule aspects of the franchises' fictional universes.

Available on YouTube (accessed on August 13, 2020).

\section{Getting clueless through the franchises}

Fans also have fun with memes using the franchises together with other topics. For jokes, they goof around based on the franchises through narrative techniques in all production paths: cosplay, simple presentation, presentation with fantasy and puppetry (Path 1); computer graphics and stop motion (Path2); presentation with fantasy (Path 3); additions on scenes, compilation, and dubbing (Path 4); and computer graphics and stop motion (Path 5). Mockeries are performed through satires based on the franchises in production paths with the following narrative techniques: cosplay, presentation with fantasy and simple presentation (Path 1); computer graphics (Path 2); presentation with fantasy (Path 3); and addition on scenes, compilation, dubbing, and subtitling (Path 4).

Jokes take place through an intertextuality between popular culture and the franchises. Thus, in a first group, fans produce 'jokes based on popularly disseminated content on the web'. To do so, they produce videos through a diversity production techniques (Paths 1-4), replacing fictional characters performing emblematic scenes in the saga for cats - one of the most popular topics on the web; using universe allusive fantasies to dance forró - one of the most popular musical rhythms in Brazil; mimicking non-human sounds of characters (i.e., Chewbacca, robots). Figure 10 shows the thumbnails from those videos, respectively.
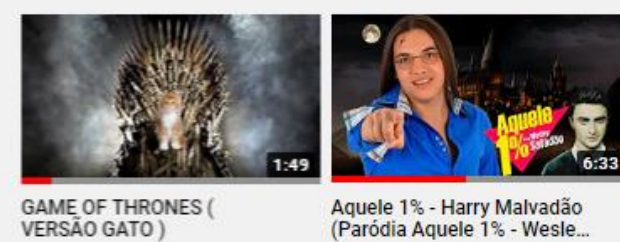

Aquele $1 \%$ - Harry Malvadão (Paródia Aquele $1 \%$ - Wesle.

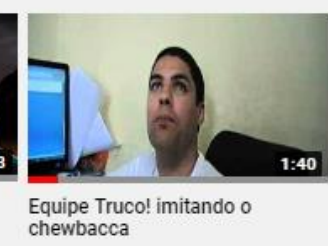

Figure 10. Fanvideo thumbnails of memes with jokes based on popularly disseminated content on the web.

Available on YouTube (accessed on August 13, 2020).

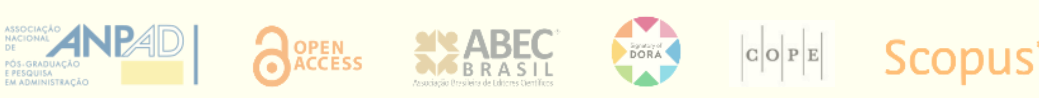


In a second group of these videos, fans produce 'jokes based on Brazilian television content', through mixed videos (Path 4). For instance, it became common videos using a scene pause effect adopted in the closing of each chapter of the one of the most famous Brazilian soap opera Avenida Brasil - in the franchises' scenes. Figure 11 shows some thumbnails that exemplify this group.

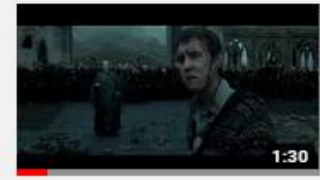

Congelamento de Avenida Brasil- Harry Potter

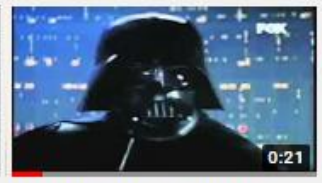

Luke Eu Sou Seu Pai. Efeito Avenida Brasil

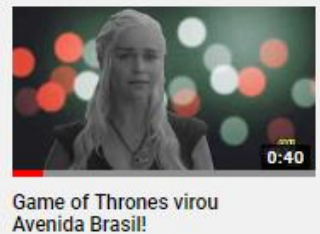

Avenida Brasil!

Figure 11. Fanvideo thumbnails of memes with jokes based on Brazilian television content.

Available on YouTube (accessed on August 13, 2020).

Regarding mockeries, fans 'represent real life based on the franchises'. In highly diverse videos (Paths 1-4), they recreate emblematic scenes of the franchises and place characters into the real world, suggesting that certain social situations seem fictional or even nonsense. We elaborated Figure 12 with a group of seven thumbnails from Star Wars-based videos, in which fans perform characters of the franchise as participating in a Big Brother-style reality show, a production format that has become very popular in the present century.

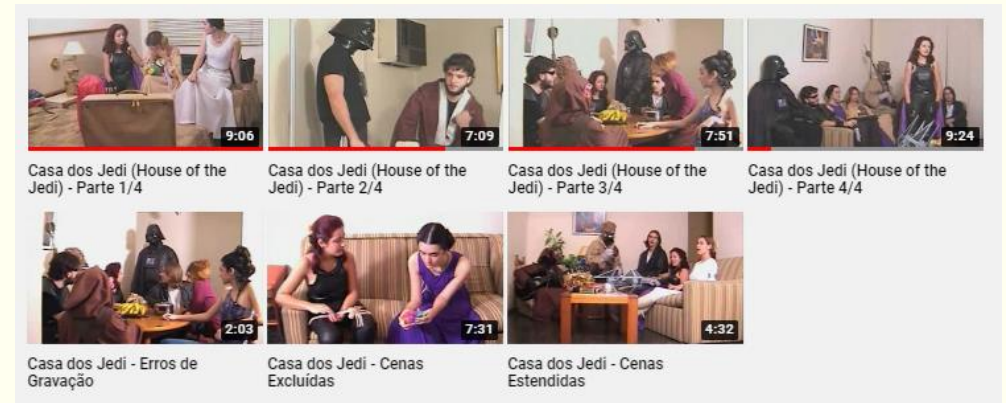

Figure 12. Fanvideo thumbnails of memes that represent real life based on the franchises.

Available on YouTube (accessed on August 13, 2020).

Fans use franchises to 'mock Brazilian social, cultural, and daily life aspects'. Original (Path 1) and mixed (Path 4) videos dwell on the poverty and public insecurity in the country, the typical Brazilian way of dealing with things, regional dialectal variations (e.g., accents, slang), football rivalry and celebrities. In a Harry Potter-based video (Figure 13), a mugger cast spells with a wand - the major weapon from a wizard - to commit a robbery. In the end, he finds out that the stolen item was pirated. 


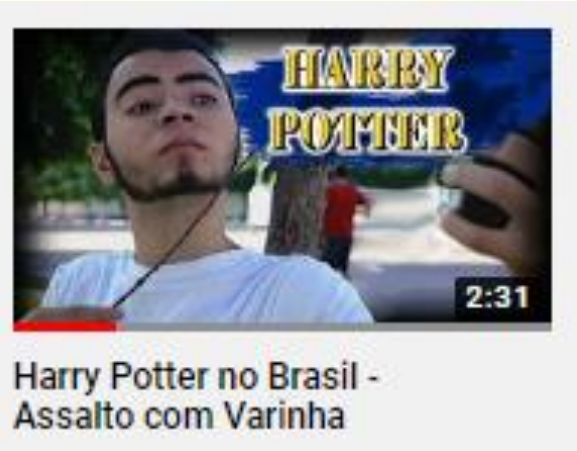

Figure 13. Fanvideo thumbnail of a meme to mock Brazilian social, cultural, and daily life aspects.

Available on YouTube (accessed on August 13, 2020).

\section{Playing dirty tricks}

Stretching the limit of play even more, franchises are put to dialogue with other themes in an obscene way and through picardy. Three paths of production are undertaken through the following narrative techniques: presentation with fantasy, simple presentation, and video clip (Path 1); computer graphics (Path 2); and additions on scenes, compilation, dubbing, subtitling, and video clip (Path 4).

A biased heteronormativity guides a recurring theme in the videos, which create humor by 'jeering non-heterosexual identities'. Issues that permeate the LGBTQI+ community are vulgarized and sexual orientations outside heteronormativity are denigrated in original (Path 1) and mixed (Path 4) videos. For example, Figure 14 shows thumbnails from videos in which fans recreate scenes by reinterpreting characters with alleged homosexual traits in a caricatured manner and using degrading terms (e.g., faggot, dyke).

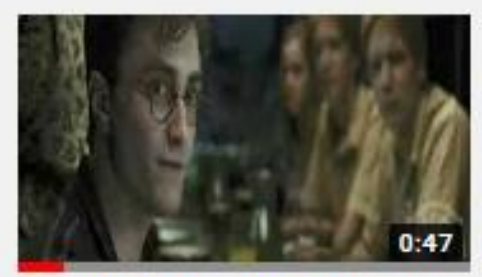

Harry potter gay-redublee

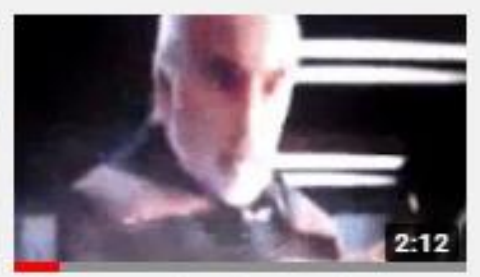

Biba wars, bichakin e obi wana VS conde deu cu

Figure 14. Fanvideo thumbnails of memes produced by jeering non-heterosexual identities.

Available on YouTube (accessed on August 13, 2020).

Fans also produce original (Path 1) and mixed (Path 4) videos 'dealing with sex-related issues', such as parental sex, sexual abuse, sex workers, and sex organs, 'in a freak and banal way'. If, in the original content, the journeys of the characters involve politics, ethical issues, and clashes between protagonists and antagonists, in the fans reinterpretations of the three franchises they only seek to realize sexual fantasies, which are portrayed in a weird way. For example, in a dubbing of a Star Wars scene, while Darth Vader passes by a guard, he tells his subordinate that he will

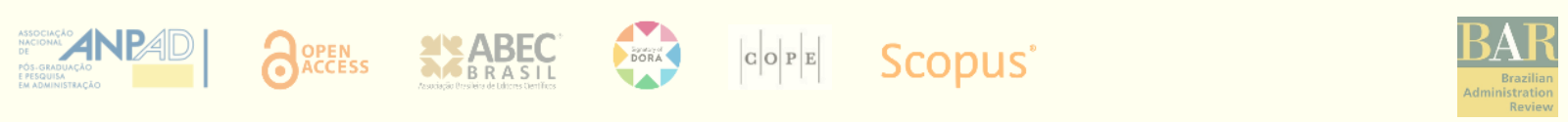


fuck (sexually speaking) all the stormtroopers (i.e., Empire soldiers) of that battalion and then they will have to fuck him back (Figure 15).

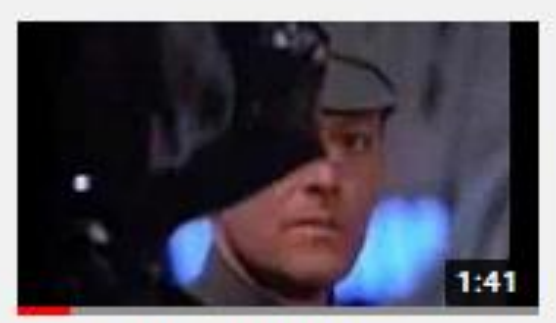

\section{Darth Vader Orgia nas}

Estrelas - dublagem

Figure 15. Fanvideo thumbnails of a meme dealing with sex-related issues in a freak and banal way.

Available on YouTube (accessed on August 13, 2020).

Finally, fans have fun 'doing eschatology'. Aspects of franchises are reinterpreted into situations involving feces, urine, and flatulence, among others. Eschatological talking and sounds (e.g., flatus) are inserted into diverse situations (e.g., romantic, serious, comedy, suspenseful scenes) of animated (Path 2) and mixed (Path 4) videos. Figure 16 shows thumbnails of videos that exemplify this group.

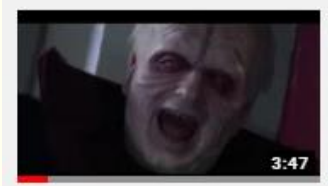

YTPBR- Star Wars e a VIngança dos Peidos

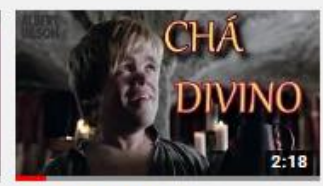

Redublagem Game of Thrones parte 1- CHÁ..

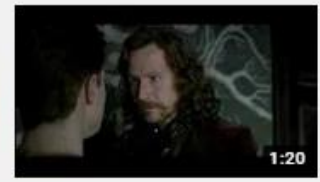

Harry Potter e os Gases Harry Potter
Flamejantes

Figure 16. Fanvideo thumbnails of memes with jokes based on eschatology.

Available on YouTube (accessed on August 13, 2020).

\section{Meming the politics}

Finally, part of the observed memetic production was centered on criticizing the Brazilian political scenario through franchises appropriation. Its production follows three paths through the following narrative techniques: cosplay and video clip (Path 1); computer graphics (Path 2); and additions on scenes, dubbing, and subtitling (Path 4).

Only fanvideos related to Game of Thrones and Star Wars were identified in this pattern. The rich material of the political game between different ruling forces present in Game of Thrones and in the epilogue trilogy of Star Wars serves as base of 'denouncing shady political interests' through animation (Path 2) and mixed videos (Path 4). A Star Wars-based fanvideo shows indignant character comments, replacing the political realm of the fictional universe with news and situations of Brazilian politics. On the other hand, some fanvideos inspired by Game of Thrones ridicule controversial aspects of Brazilian politics (e.g., 2014 election results, presidential 
impeachment) by comparing them to the saga's political plots, notably woven by disputes, intrigue, and violence. Figure 17 presents thumbnails from videos that illustrate this pattern.

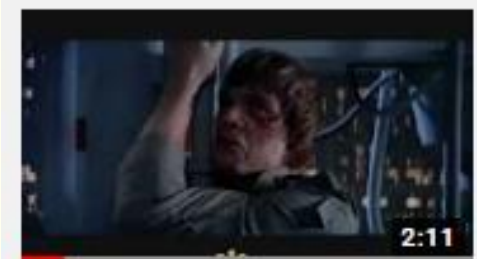

Luke, Lula é seu pai!

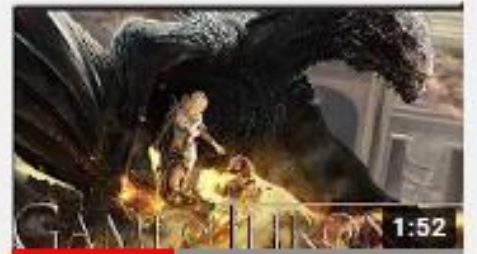

0 Impeachment de Daenerys - Game of Thrones...

Figure 17. Fanvideo thumbnails of memes with shady political interests.

Available on YouTube (accessed on August 13, 2020).

Besides, villains, especially those of Star Wars, are used to characterize malignant political forces. Star Wars-based original (Path 1) and mixed (Path 4) fanvideos make a comparison between franchise villains and the most controversial Brazilian politicians at the time when these videos were posted (e.g., Dilma Rouseff, Michel Temer). Such politicians are portrayed as the franchise villains, depicting evil real-world impersonations. Figure 18 shows a thumbnail of a video that compares Brazil's former president (i.e., Michel Temer) to Star Wars' major villain (i.e., Darth Sidious).

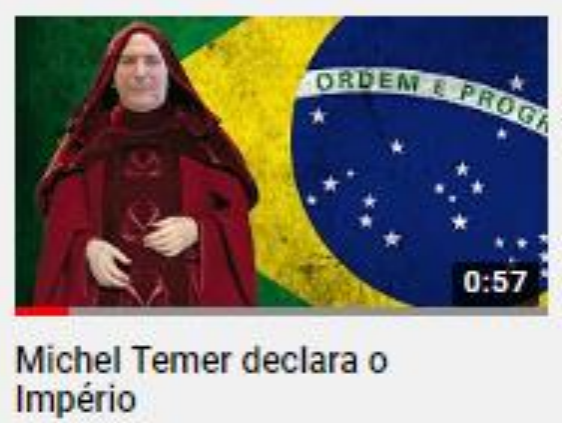

Figure 18. Fanvideo thumbnails of a meme used to characterize malignant political forces.

Available on YouTube (accessed on August 13, 2020).

The non-appearance of references to the Harry Potter universe in this pattern may relate to a difference in fandom age. Despite being a political saga in some way, in our data, this fandom does not directly and explicitly exploit compromising issues related to government politics.

\section{MAKING SENSE OF THE RESULTS THROUGH THEORETICAL FOUNDATION}

Based on the results obtained in our analysis, it is possible to understand that the process of memetic production in fanvideos manifests different spectra of socialization. At an initial level, as to the form that the process is taken, the appropriation of information and communication technologies (ICT) and the creativity to make use of different techniques of video production

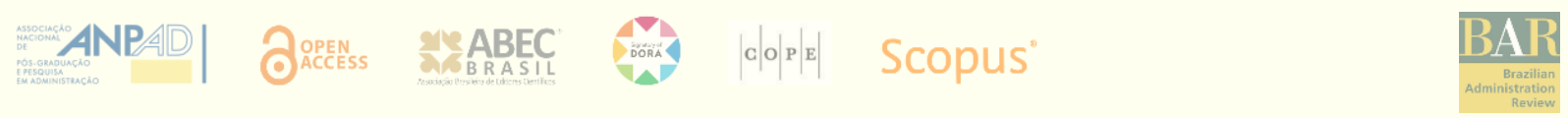


evidence how the fan culture overlaps the participatory culture of technological appropriation (Guschwan, 2012; Jenkins, 2006). When it comes to the themes treated in the memetic fanvideos, it is possible to observe a cultural production that explicitly evokes playfulness, since fun and hedonic consumption experience guide the fans to unite with their peers (Fathallah, 2016). From this point, however, an agenda of social criticism arises in the way that fans converge cultural texts to their political positions and ideologies (Burwell \& Boler, 2008) and, on the other hand, prejudice manifestations built as layers that are not part of the fictional universes (Young, 2014).

The fanvideos analyzed reveal a wide diversity of narrative techniques and styles. A range of combinations of original materials with those taken from the franchises and third parties is combined in numerous production types, which evidence both the ability of fans to appropriate available technologies and to exercise their creativity. Regarding the technological appropriation, Jenkins (2006) argues that this is one of the pillars of participatory culture; since this is a digitally mediated culture, the ability to deal with digital technologies becomes paramount. On the other hand, Chen (2018) claims that fans seek to express themselves creativity by producing content related to popular culture products; fan culture is distinguished by the interaction, signification, imagination, and materialization of new content that expresses a creative attitude (Chen \& Chandler, 2010; Seregina \& Weijo, 2016).

Memes have intertextual and interdiscursive characteristics, which allows them to popularize the subjects they deal with (Bellar, Campbell, Cho, \& Terry, 2013). This occurs because memes appropriate widespread texts and discourses and add new layers of meaning to them (Huntington, 2015). Regarding the franchises on which their fanvideos are based, fans produce memes ranging from exaltation to depreciation. Even in the latter situation, we do not identify a work of haters, but of fans who feel able and comfortable in making criticisms or jokes of questionable taste. We understand that behind such practice lies the intimacy that fans develop with popular culture texts. This intimacy reveals shared values among fans and what they interpret about the fictional universes (see Busse \& Gray, 2011; Hackley \& Hackley, 2018). This is evident from the fact that most of the meanings shown up on the fanvideos require prior knowledge of the franchises. It is characteristic of fan culture that fans deeply know the original content of the works with which they are linked and easily remember details about them (Hills, 2002).

This knowledge and closeness enable fans to make connections between popular culture and social life (Huntington, 2015; Milner, 2013), as evidenced by our findings when franchises are used as mediation to address social, cultural, and political issues on the fanvideos. Through their humorous appeal, memes address complex issues (Bellar et al., 2013; Milner, 2013) so that fans can express political opinions about contemporary events (Hinck \& Davisson, 2020). The use of humor to express opinions is a strategy of inserting them in discourses typically dominated by traditional media agenda (Hinck \& Davisson, 2020). More than this, meme genre provides something that marketers' strategies cannot do: spontaneous participation, speed, dialogue between consumers (see Shifman, 2012).

It is characteristic of memes to adopt a satirical tone, ranging from the use of double meanings, metaphors, and ironies, to profanity and eschatology (Vitiuk, Polishchuk, Kovtun, \& Fed, 2020). 
Fans typically seek to resonate their productions to the fullest and find in this language a strong appeal; their intention is to provoke laughter through messages ranging from kidding to picardy, to achieve great popularity (Hinck \& Davisson, 2020; Zannete et al., 2019). In our findings we found out how such a posture reveals a wide threshold that include everything from childish jokes to veiled prejudices that hide within the humor.

Amongst this variety of positions, we conclude that the content appropriation of successful popular culture franchises for memetic production broadens the resonance of such media texts both in terms of their own fictional universes and on their possibility to dialogue with the social world. By expanding the reach of media texts, fans enhance their spread (Jenkins et al., 2013), acting productively (Ritzer et al., 2012). On the other hand, fanvideo meme production looks analogous to fanfiction, enabling fans to 'write' new pages on the fictional universes they are attach to (see Thomas, 2011).

Still, there is a political facet to the fan culture activities (Chen, 2018). When added to the possibilities of production and reproduction of content on YouTube (i.e., through practices of appropriation and remix of content), they manifest and legitimize a democratizing force, respecting or not the conception of copyright (Burgess \& Green, 2009). Therefore, it is possible to see in these productions a set of intertextual operators that legitimize a glocalization, when consumers are adapting global speeches locally (Androutsopoulos, 2010; Kizgin et al., 2018).

Nevertheless, the interface of this process with social life makes room for a reproduction of prejudiced practices that target stigmatized identities. It is intriguing that this happens in the context of popular culture, since the fans are often discriminated for being considered fanatics or nerds and end up using their uniqueness character of consumption to develop a sense of pride and sustain their identity (Booth, 2013).

This set of features can be understood within the scope of consumers' ability to deal productively and creatively with media texts reception. On this point, Kozinets (2001) argued that, because there is a fluid and complex interaction between fans, fandoms, popular culture, and the entertainment industry (i.e., individuals, subculture, wider culture, and cultural producers), it is possible to observe an active process in the reception of media texts, where fans present different forms of communicational skills to deal with the media codes.

For his purpose, Kozinets (2001) resorts to Stuart Hall's encoding/decoding theory. In order to criticize the linear conception of communicational models, Hall (1980) argued that media texts communication is established at different moments that are articulated between production, distribution, circulation, and consumption. Thus, encoding is not a process reducible to the production moment; it is performed also during the distribution and circulation of the media texts. On the other hand, decoding is not a passive act of receiving messages; it is an active process of interpretation affected by personal experience, by the context of the circulation of messages and by the way they are distributed.

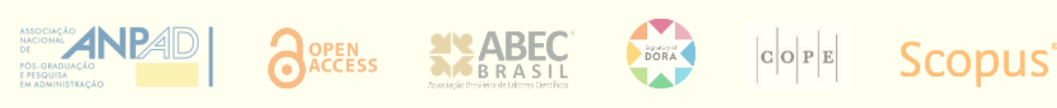


We understand that by expressing themselves through fanvideo meme production, fans go beyond (re)interpreting (i.e., decoding) the media texts they receive (i.e., encoding). Since it is a new content based on a previous produced one, we argue that, in the terms of the encoding/decoding theory logic, this is a process of 'recoding' the media text. The new text (i.e., fanvideo meme) is no longer a continuity of the original one; nonetheless, it is only possible to exist and to be understood in the light of it.

\section{CONCLUDING REMARKS}

The fans' way to express themselves through fanvideo meme production can be considered in different fronts. Firstly, one can highlight the versatility and variety of types of performances and techniques adopted in these productions. In addition, it draws attention that the fanvideos discuss the fictional universes on which they are based, as well as dialogues with different spheres of social life based on such narratives. Finally, it is relevant to reflect on the way humor is adopted, either in its different tones or in its purposes. As theoretical contribution, these outcomes show how productive consumer behavior collapses with other social spheres when skilled creative consumer practices appropriate and re-signify the meaning of products and brands. Specifically speaking, meme production and fan culture can be considered topics proper do CCT but are still in the process of developing a research agenda in this field. The association of these themes with the concept of prosumption permeates an interdisciplinary theoretical articulation that is inherent to the foundations of this research field. Complementary, the fanvideos analyzed express practices and techniques that are typical of fan culture, and the tone and style adopted align with the conception of meme production.

Due to the scope of the research, the themes addressed and the way they are treated reveal characteristics that can be attributed to aspects of Brazilian culture. We can understand this as a limitation of the study, but it also brings another contribution in terms of the uniqueness of the findings, suggesting a cultural influence on this type of production, as an indication of the possibility of expanding this knowledge by considering the investigation of other cultures. Hence, the purpose of the present study is in line with a broader investigation of memetic fanvideo production; added to other discursive and cultural contexts, it could start a theoretical formulation about the relationship between memes, popular culture, and social life in a process of 'recoding' media texts.

On the flip side, such aspects also represent practical implications. They can be points of interest for marketing practice, since the skills and meaning-making process of prosumers can work favorably (e.g., as market agencement) or unfavorably (e.g., distorting desirable meaning) for the brands. In social terms, in turn, this process opens space for ethical consideration, since it deals both with the limits of copyrights and with prejudiced behavior.

In order to complement what we presented in this study, it seems to us that a possible way to explore the marketing capacity of memes is to think of franchises as brands, establishing a dialogue between branding strategies and meme production on Web 2.0. Other interesting paths would be to consider the issue of glocalization that was explored here (i.e., global discourses being

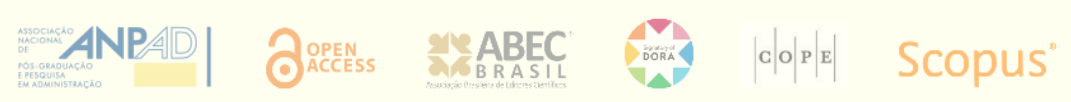


adapted locally by consumers) or a more critical bias deepening the political aspects (i.e., prejudices, socio-cultural changes) manifested in fannish practices.

\section{ACKNOWLEDGEMENTS}

National Council for Scientific and Technological Development (CNPq) supported the research. Coordination for the Improvement of Higher Education Personnel (Capes) supports the graduate program to which the researchers are affiliated.

\section{Funding}

Ministério da Ciência, Tecnologia e Inovação, Conselho Nacional de Desenvolvimento Científico e Tecnológico

\section{REFERENCES}

Ahuvia, A. (2001). Traditional, interpretive, and reception-based content analyses: Improving the ability of content analysis to address issues of pragmatic and theoretical concern. Social Indicators Research, 54(2), 139-172. https://doi.org/10.1023/A:1011087813505

Androutsopoulos, J. (2010). Localizing the global on the participatory web. In: N. Coupland (Ed.), The handbook of language and globalization (pp. 203-231). Sussex: John Willey \& Sons.

Arvidsson, A., \& Caliandro, A. (2015). Brand Public. Journal of Consumer Research, 42(5), 727-748. https://doi.org/10.1093/jcr/ucv053

Bauer, M., \& Aarts, B. (2002). Corpus construction: A principle for qualitative data collection. In M. Bauer, \& G. Gaskell (Eds.), Qualitative researching with text, image and sound. (pp. 19-37). London: Sage.

Baxter, L. A. (1991). Content analysis. In B. M. Montgomery, \& S. Duck (Eds.), Studying interpersonal interaction (pp. 239-254). New York, NY: Guilford Press.

Bellar, W., Campbell, H, Cho, K. J, \& Terry, A. (2013). Reading religion in internet memes. Journal of Religion, Media and Digital Culture, 2(2), 1-39. https://doi.org/10.1163/21659214-90000031

Bishop, S. (2018). Anxiety, panic and self-optimization: inequalities and the YouTube algorithm. Convergence, 24(1), 69-84. https://doi.org/10.1177/1354856517736978

Booth, P. (2013). Augmenting fan/academic dialogue: New directions in fan research. The Journal of Fandom Studies, 1(2), 119-137. https://doi.org/10.1386/jfs.1.2.119_1

Boulaire, C., Hervet, G., \& Graf, R. (2010). Creativity chains and playing in the crossfire on the video-sharing site YouTube. Journal of Research in Interactive Marketing, 4(2), 111-141. https://doi.org/10.1108/17505931011051669

Burgess, J., \& Green, J. (2009). YouTube e a revolução digital: Como o maior fenômeno da cultura participativa transformou a midia e a sociedade. São Paulo: Aleph.

Burwell, C., \& Boler, M. (2008). Calling on the colbert nation: Fandom, politics and parody in an age of media convergence. Electronic Journal of Communication, 18 (2-4), 1-25. Retrieved from http://www.cios.org/www/wjc/ejcpublic/018/2/01845.html

Busse, K., \& Gray, J. (2011). Fan cultures and fan communities. In V. Nightingale (Ed.), The handbook of media audiences (pp. 425-443). New Jersey: Wiley-Blackwell.

Chen, K. (2011). Artistic presumption: Cocreative destruction at burning man. American Behavioral Scientist, 56(4), 570-595. https://doi.org/10.1177/0002764211429362

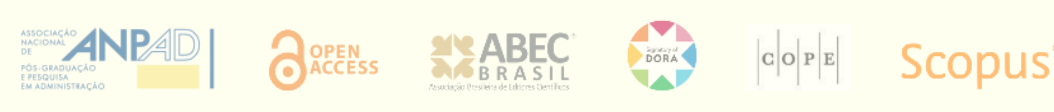


Chen, Z. T. (2018). Poetic prosumption of animation, comic, game and novel in a post-socialist China: A case of a popular video-sharing social media Bilibili as heterotopia. Journal of Consumer Culture. https://doi.org/10.1177/1469540518787574

Chen, S., \& Chandler, J. (2010). Design it, your self-experiences (DIY): Social creativity and the social function of DIY". Advances in Consumer Research, 37(1), 775-776. Retrieved from https://www.acrwebsite.org/volumes/15329/volumes/v37/NA-37

Christodoulides, G., Jevons, C., \& Bonhomme, J. (2012). Memo to marketers: Quantitative evidence for change. Journal of Advertising Research, 52(1), 53-64. https://doi.org/10.2501/JAR-52-1-053-064

Collins, S. (2010), Digital Fair: Prosumption and the fair use defence. Journal of Consumer Culture, 10(1), 37-55. https://doi.org/10.1177/1469540509354014

Cova, B., \& Cova, V. (2012). On the road to prosumption: Marketing discourse and the development of consumer competencies. Consumption Markets E Culture, 15(2), 149-168. http://doi.org/10.1080/10253866.2012.654956

Cova, B., Dalli, D., \& Zwick, D. (2011). Critical perspectives on 'consumers' role as 'producers': Broadening the debate on value co-creation in marketing processes. Marketing Theory, 11(3), 231-241. https://doi.org/10.1177/1470593111408171

Daugherty, T., Eastin, M., \& Bright, L. (2008). Exploring consumer motivations for creating user-generated content. Journal of Interactive Advertising, 8(2), 16-25. https://doi.org/10.1080/15252019.2008.10722139

Delwiche, A., \& Henderson, J. (2012). The participatory cultures handbook. New York: Routledge.

Drisko, J. W., \& Maschi, T. (2015). Content analysis. New York, NY: Oxford University Press.

Duffett, M. (2013). Understanding fandom: An introduction to the study of media fan culture. London: Bloomsbury Publishing.

Fathallah, J. (2016). 'Except that Joss Whedon is god': Fannish attitudes to statements of author/ity. International Journal of Cultural Studies, 19(4), 459-476. https://doi.org/10.1177/1367877914537589

Flick, U. (2006). An Introduction to qualitative research. London: Sage Publications.

Freund, K. (2016). 'Fair use is legal use': Copyright negotiations and strategies in the fan-vidding community. New Media $\mathcal{E}$ Society, 18(7), 1347-1363. https://doi.org/10.1177/1461444814555952

Guadagno, R., Rempala, D., Murphy, S., \& Okdie, B. (2013). What makes a video go viral? An analysis of emotional contagion and Internet memes. Computers in Human Behavior, 29(6), 2312-2319. https://doi.org/10.1016/j.chb.2013.04.016

Guschwan, M. (2012). Fandom, brandom and the limits of participatory culture. Journal of Consumer Culture, 12(1), 19-40. https://doi.org/10.1177/1469540512438154

Hackley, C., \& Hackley, A. R. (2018). Advertising at the threshold: Paratextual promotion in the era of media convergence. Marketing Theory, 19(2), 195-215. https://doi.org/10.1177/1470593118787581

Hall, S. (1980). Encoding/Decoding. In: S. Hall, D. Hobson, A. Lowe, \& P. Willis (Eds.), Culture, media, language (pp. 128-140). London: Hutchinson.

Hartmann, B. J. (2015). Peeking behind the mask of the prosumer: Theorizing the organization of consumptive and productive practice moments. Marketing Theory, 16(1), 3-20. https://doi.org/10.1177/1470593115581722

Hayashi, P. Jr; Abib, G., \& Hoppen, N. (2019). Validity in qualitative research: A processual approach. The Qualitative Report, 24(1), 98-112. Retrieved from https://nsuworks.nova.edu/tqr/vol24/iss1/8/

Hilderbrand, L. (2007). Youtube: Where cultural memory and copyright converge. Film Quarterly, 61(1), 48-57. https://doi.org/10.1525/fq.2007.61.1.48

Hills, M. (2002). Fan cultures. London: Routledge.

Hills, M. (2010). Triumph of a time lord: Regener-ating Doctor Who in the twenty-first century. London: I. B. Tauris.

Hills, M. (2013). Fiske's 'textual productivity' and digital fandom: Web 2.0 democratization versus fan distinction? Participations: Journal of Audience $\mathcal{E}$ Reception Studies, 10(1), 130-153. Retrieved from https://www.participations.org/Volume\%2010/Issue\%201/9\%20Hills\%2010.1.pdf

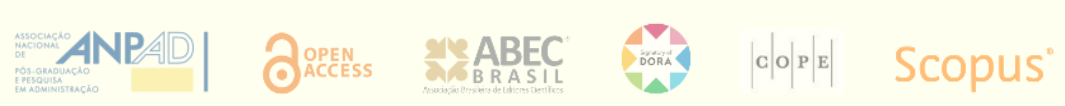


Hinck, A., \& Davisson, A. (2020). Fandom and Politics. Transformative Works and Cultures, 32(special issue). https://doi.org/10.3983/twc.2020.1973.

Huntington, H. E. (2015). Pepper spray cop and the American dream: Using synecdoche and metaphor to unlock internet memes visual political rhetoric. Communication Studies, 67(1), 77-93. https://doi.org/10.1080/10510974.2015.1087414

Jenkins, H. (1992). Textual poachers: Studies in culture and communication. New York, NY: Routledge.

Jenkins, H. (2003). Quentin Tarantino's Star Wars? Digital cinema, media convergence, and participatory culture. In D. Thorburn \& H. Jenkins (Eds.), Rethinking media change: The aesthetics of transition (pp. 281-312). Cambridge: MIT Press.

Jenkins, H. (2006). Fans, Bloggers, and gamers: Exploring participatory culture. New York, NY: New York University Press.

Jenkins, H. (2009). Confronting the Challenges of Participatory Culture: Media Education for the 21st Century. Cambridge: The MIT Press.

Jenkins, H., Ford, S., \& Green, J. (2013). Spreadable media: Creating value and meaning in a networked culture. New York, NY: New York University Press.

Jung, S., \& Shim, D. (2014). Social distribution: K-pop fan practices in Indonesia and the 'Gangnam Style' phenomenon. International Journal of Cultural Studies, 17(5) 485-501. https://doi.org/10.1177/1367877913505173

Kligler-Vilenchik, N., \& Thorson, K. (2016). Good citizenship as a frame contest: Kony2012, memes, and critiques of the networked citizen. New Media E Society, 18(9), 1993-2011. https://doi.org/10.1177/1461444815575311

Kizgin, H., Jamal, A., \& Richard, M. (2018). Consumption of products from heritage and host cultures: The role of acculturation attitudes and behaviors. Journal of Business Research, 82(1), 320-329. https://doi.org/10.1016/j.jbusres.2017.09.011

Kotler, P. (1986). The prosumer movement: A new challenge for marketers. In R. J. Lutz (Ed.), Advances in Consumer Research (pp. 510-513). Provo: Association for Consumer Research.

Kozinets, R. V. (2001). Utopian enterprise: Articulating the meanings of Star Trek 's culture of consumption. Journal of Consumer Research, 28(1), 67-88. https://doi.org/10.1086/321948

Knobel, M., \& Lankshear, C. (2007). Online memes, affinities and cultural production. In: M. Knobel \& C. Lankshear (Eds), A New Literacies Sampler (pp. 199-227). New York: Peter Lang.

Laughey, D. (2010). Media Studies. London: Oldcastle Books.

Leão, A. L. M. S., Mello, S. C., \& Vieira, R. S. G. (2009). O papel da teoria no método de pesquisa em Administração. Revista Organizações em Contexto, 5(10), 1-16. https://doi.org/10.15603/1982-8756/roc.v5n10p1-16

Lévy, P. (1997). Collective Intelligence: Mankind's Emerging World in Cyberspace. New York, NY: Plenum.

Martens, M. (2019). The forever fandom of Harry Potter: Balancing fan agency and corporate control. Cambridge: Cambridge University Press.

Mckenzie, P., Burkell, J. A., Wong, \&. Whippey, C. (2012). User-generated online content 1: Overview, current state and context. First Monday, 17(6). https://doi.org/10.5210/fm.v17i6.3912

Miles, M., Huberman, A., \& Saldana, J. (2014). Qualitative data analysis: A methods sourcebook. (3th ed.). Thousand Oaks, CA: Sage Publications.

Milkoreit, M. (2019). Pop-cultural mobilization: deploying Game of Thrones to shift US cli-mate change politics. International Journal of Politics, Culture, and Society, 32(1), 61-82. https://doi.org/10.1007/s10767-017-9273-7

Milner, R. M. (2013). Pop polyvocality: Internet memes, public participation, and the occupy Wall Street movement. International Journal of Communication, 7(1), 2357-2390. Retrieved from https://www.researchgate.net/publication/281562752_Pop_Polyvocality_Internet_Memes_Public_Participatio n_and_the_Occupy_Wall_Street_Movement

Mina, A. X. (2019). Memes to movements: How the world's most viral media is changing social protest and power. Boston: Beacon Press

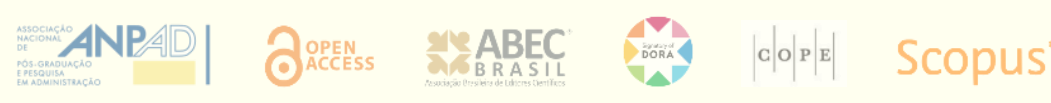


Morreale, J. (2013). From homemade to store bought: Annoying orange and the professionalization of YouTube. Journal of Consumer Culture, 14(1), 113-128. https://doi.org/10.1177/1469540513505608

Muntinga, D. G., Moorman, M., \& Smit, E. G. (2011). Introducing COBRAs: Exploring motivations for brandrelated social media use. International Journal of Advertising, 30(1), 13-46. https://doi.org/10.2501/IJA-30-1-013046

Neville, L. (2018). Girls Who like boys who like boys: Women and gay male pornography and erotica. London: Palgrave.

Nissenbaum, A., \& Shifman, L. (2015). Internet memes as contested cultural capital: The case of 4chan's /b/ board. New Media EO Society, 19(4), 483-501. https://doi.org/10.1177/1461444815609313

Paiva F. G., Jr., Leão, A. L. M. S., \& Mello, S. C. (2011). Validade e confiabilidade na pesquisa qualitativa em administração. Revista de Ciências da Administração, 13(31), 190-209. https://doi.org/10.5007/2175. 8077.2011 v13n31p190

Papailias, P. (2018). (Un)seeing dead refugee bodies: Mourning memes, spectropolitics, and the haunting of Europe. Media, Culture EF Society, https://doi.org/10.1177/0163443718756178

Peñaloza, L. (1994). Atravesando fronteras/border crossings: A critical ethnographic exploration of the consumer acculturation of Mexican immigrants. Journal of Consumer Research, 21(1), 32-54. https://doi.org/10.1086/209381

Phillips, W. (2019). It wasn't just the trolls: Early internet culture, "fun," and the fires of exclusionary laughter. Social Media + Society, 5(3), 1-4. https://doi.org/10.1177/2056305119849493

Ritzer, G. (2014). Prosumption: Evolution, revolution, or eternal return of the same? Journal of Consumer Culture, 14(1), 3-25. https://doi.org/10.1177/1469540513509641

Ritzer, G., Dean, P., \& Jurgenson, N. (2012). The coming of age of the prosumer. American Behavioral Scientist, 56(4), 379-398. https://doi.org/10.1177/0002764211429368

Ritzer, G., \& Jurgenson, N. (2010). Production, consumption, presumption: The nature of capitalism in the age of the digital 'prosumer'. Journal of Consumer Culture, 10(1), 13-36. https://doi.org/10.1177/1469540509354673

Ross, A. S., \& Rivers, D. J. (2017). Digital cultures of political participation: Internet memes and the discursive delegitimization of the 2016 U.S Presidential candidates. Discourse, Context $\mathcal{F}$ Media, 16, 1-11. https://doi.org/10.1016/j.dcm.2017.01.001

Sandvoss, C. (2005). Fans: The mirror of consumption. Cambridge: Polity Press.

Sarikakis, K., Krug, C., \& Rodriguez-Amat J. (2015). Defining authorship in user-generated content: Copyright struggles in The Game of Thrones. New Media $\mathcal{E}$ Society, 19(4), $542-559$. https://doi.org/10.1177/1461444815612446

Seregina, A., \& Weijo, H. A. (2016). Play at any cost: How cosplayers produce and sustain their ludic communal consumption experiences. Journal of Consumer Research, 44(1), 139-149. https://doi.org/10.1093/jcr/ucw077

Shifman, L. (2012). An anatomy of a YouTube meme. New Media Eु Society, 14(2), 187-203. https://doi.org/10.1177/1461444811412160

Shifman, L. (2014). The cultural logic of photo-based meme genres. Journal of Visual Culture, 13(3), 340-358. https://doi.org/10.1177/1470412914546577

Souza-Leão, A. L. M., \& Costa, F. Z. N. (2018). Assemblaged by desire: Potterheads' productive consumption. Revista de Administração de Empresas, 58(1), 74-86. http://dx.doi.org/10.1590/s0034-759020180107

Stein, L., \& Busse, K. (2009). Limit play: Fan authorship between source text, intertext and context. Popular Communication, 7(4), 192-207. https://doi.org/10.1080/15405700903177545

Stuart-Menteth, H., Wilson, H., \& Baker, S. (2006). Escaping the channel silo: Researching the new consumer. International Journal of Market Research, 48(4), 415-437. https://doi.org/10.1177/147078530604800405

Sugihartati, R. (2020). Youth fans of global popular culture: Between prosumer and free digital labourer. Journal of Consumer Culture, 20(3), 305-323. https://doi.org/10.1177/1469540517736522

Tapscott, D., \& Williams A. D. (2006). Wikinomics: How mass collaboration changes everything. New York, NY: Penguin. 
Taylor, C. (2014). How Star Wars conquered the universe: The past, present, and future of a multibillion-dollar franchise. London: Head of Zeus.

Timmermans, S., \& Tavory, I. (2012). Theory construction in qualitative research: From grounded theory to abductive. Sociological Theory, 30(3), 167-186. https://doi.org/10.1177/0735275112457914

Thomas, B. (2011). What is fanfiction and why are people saying such nice things about it? Storyworlds: A Journal of Narrative Studies, 3, 1-24. https://doi.org/10.5250/storyworlds.3.2011.0001

Toffler, A. (1980). The third wave. New York: Bantam Books.

Van Dijck, J. (2009). Users like you? Theorizing agency in user-generated content. Media, Culture E⿱ Society, 31(1), 41-58.

Van Dijck, J. (2013). The culture of connectivity: A critical history of social media. New York: Oxford University Press.

Vitiuk, I., Polishchuk, O., Kovtun, N., \& Fed, V. (2020). Memes as the phenomenon of modern digital culture. WISDOM, 15(2), 45-55. https://doi.org/10.24234/wisdom.v15i2.361

Wang, J., \& Wang, H. (2015). From a marketplace to a cultural space. Journal of Technical Writing and Communication, 45(3), 261-274. https://doi.org/10.1177/0047281615578847

Wiggins, B. E., \& Bowers, G. B. (2014). Memes as genre: A structurational analysis of the memescape. New Media $\mathcal{E}$ Society, 17(11), 1886-1906. https://doi.org/10.1177/1461444814535194

Wood, R. (2020). "What I'm not gonna buy': Algorithmic culture jamming and anti-consumer politics on YouTube. New Media $\mathcal{E}$ Society. https://doi.org/10.1177/1461444820939446

Wu, Y., \& Ardley, B. (2007). Brand strategy and brand evolution: Welcome to the world of the meme. The Marketing Review, 7(3), 301-310. https://doi.org/10.1362/146934707X230112

Young, H. (2014). Race in online fantasy fandom: Whiteness on Westeros.org. Continuum, 28(5), 737-747. https://doi.org/10.1080/10304312.2014.941331

Zajc, M. (2015). Social media, prosumption, and dispositives: New mechanisms of the construction of subjectivity. Journal of Consumer Culture, 15(1), 28-47. https://doi.org/10.1177/1469540513493201

Zanette, M. C., Blikstein, I., \& Visconti, L. M. (2019). Intertextual virality and vernacular repertoires: Internet memes as objects connecting different online worlds. Revista de Administração de Empresas, 59(3), 157-169. http://dx.doi.org/10.1590/s0034-759020190302

\section{Author contributions}

1st author: conceptualization (lead); data curation (lead); formal analysis (equal); funding acquisition (lead); investigation (equal); methodology (lead); project administration (lead); resources (lead); supervision (lead); validation (equal); visualization (lead); writing - original draft (equal); writing - review \& editing (equal).

2nd author: conceptualization (supporting); data curation (supporting); formal analysis (equal); investigation (equal); methodology (supporting); supervision (supporting); validation (equal); visualization (supporting); writing - original draft (equal); writing - review \& editing (equal).

3rd author: conceptualization (supporting); formal analysis (equal); investigation (equal); methodology (supporting); validation (equal); writing - original draft (equal); writing - review \& editing (supporting).

4th author: conceptualization (supporting); formal analysis (equal); investigation (equal); methodology (supporting); validation (equal); writing - original draft (equal); writing - review \& editing (supporting).

5th author: conceptualization (supporting); formal analysis (equal); investigation (equal); methodology (supporting); validation (equal); writing - original draft (equal); writing - review \& editing (supporting).

\section{Authors}

André Luiz Maranhão de Souza-Leão *

Universidade Federal de Pernambuco, Recife, PE, Brazil

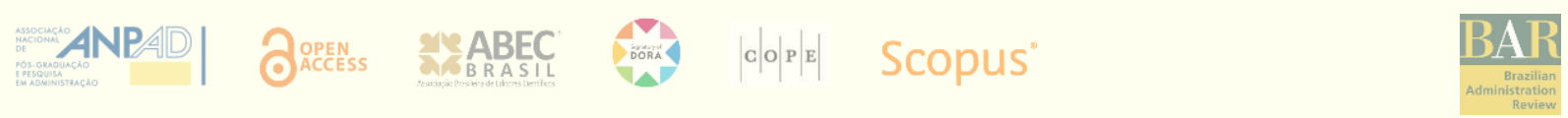


Av. Prof. Moraes Rego, n 1235, Cidade Universitária, 50670-901, Recife, PE, Brazil andre.sleao@ufpe.br, desouzaleao.pq@gmail.com

(D) https://orcid.org/0000-0002-7660-5845

\section{Bruno Melo Moura}

Universidade Federal de Pernambuco, Recife, PE, Brazil

Av. Prof. Moraes Rego, n 1235, Cidade Universitária, 50670-901, Recife, PE, Brazil bmouratop@outlook.com

(iD) https://orcid.org/0000-0002-8205-4576

\section{Vitor de Moura Rosa Henrique}

Universidade Federal de Pernambuco, Recife, PE, Brazil

Av. Prof. Moraes Rego, n 1235, Cidade Universitária, 50670-901, Recife, PE, Brazil vitormourarh@gmail.com

(iD) https://orcid.org/0000-0003-1792-7382

\section{Walber Kaíc da Silva Nunes}

Universidade Federal de Pernambuco, Recife, PE, Brazil

Av. Prof. Moraes Rego, n 1235, Cidade Universitária, 50670-901, Recife, PE, Brazil nuneswalber@gmail.com

(iD) https://orcid.org/0000-0002-2639-0946

\section{Italo Rogerio Correia de Santana}

Universidade Federal de Pernambuco, Recife, PE, Brazil

Av. Prof. Moraes Rego, no 1235, Cidade Universitária, 50670-901, Recife, PE, Brazil italocorreia2010@hotmail.com

(iD https://orcid.org/0000-0003-3145-9124

* Corresponding author

Peer review is responsible for acknowledging an article's potential contribution to the frontiers of scholarly knowledge on business or public administration. The authors are the ultimate responsible for the consistency of the theoretical references, the accurate report of empirical data, the personal perspectives, and the use of copyrighted material.

This content was evaluated using the double-blind peer review process. The disclosure of the reviewers' information on the first page is made only after concluding the evaluation process, and with the voluntary consent of the respective reviewers. 